\title{
Effect of Quercetin on Rhinitis via Inflammatory Pathway
}

\author{
Yuan Xing, Congming Tan, Yan Luo and Wenjun Liu* \\ Otolaryngology Head and Neck Surgery, Hong Hui Hospital, Xi'an Jiaotong University, \\ No. 555 Youyi East Road, Beilin District, Xi'an City, Shaanxi Province,710054, China
}

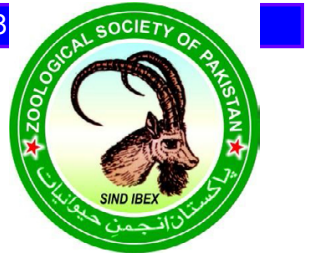

\begin{abstract}
A B S T R A C T
Asthma is a chronic inflammatory airway disease, characterized by reversible goblet cells, smooth muscle hyperplasia, airflow obstruction, hyperactivity enhanced, ultra-structural remodeling, and airway mucus production. The current experimental study was aimed at scrutinizing quercetin's inhibitory effect on airway inflammation in mice and its possible mechanism of action. The mice received varying doses of quercetin from 22-30 days (1, 10 and $50 \mathrm{mg} / \mathrm{kg}$, p.o.) and montelukast (10 mg / kg, p.o.). Intranasal OVA has been instilled on the 21 days. Biochemical parameters, spleen weight, physiological parameters, interleukin (IL-1 $\beta$ and IL-6) parameters and immunoglobin-E (IgE) were calculated at the end of the experimental study. To investigate the potential mechanism of action, Paw edema and mast cell degranulation are estimated. Used to measure immune and inflammatory mediators, qRT-PCR technique. Quercetin significantly $(\mathrm{P}<0.001)$ reduced $\mathrm{IgE}$ levels in the asthma mice serum. Inflammatory cells in the mice BALF are significantly reduced in a dose-dependent manner through quercetin. Quercetin $(\mathrm{P}<0.05)$ significantly reduced the level of TNF- $\alpha$, IL-1 $\beta$, IL-4 and IL-5 cytokines and increased the level of IFN- $\pi$ in allergic asthma mice caused by OVA. In contrast, there was no significant effect in the body weight of mice treated with quercetin. Based on the result, we may infer that quercetin demonstrates an inflammatory mechanism for the therapeutic effect of inflammation in allergic asthma.
\end{abstract}

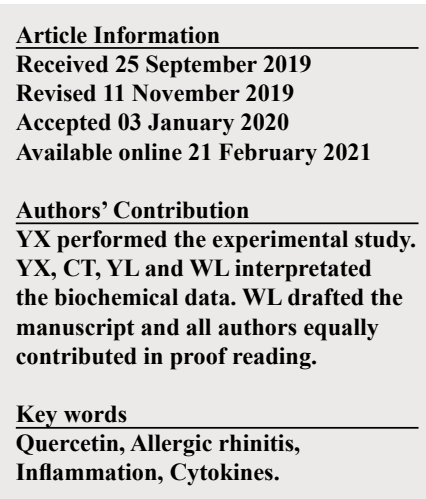

\section{INTRODUCTION}

$\mathrm{A}$ llergic rhinitis (AR) is a subsequent nasal mucosal inflammation which causes a spontaneous hypersensitivity reaction to immunoglobulin $\mathrm{E}$ ( $\operatorname{IgE}$ ), characterized by symptoms such as running eyes, itchy nose, nasal congestion, sneezing, rhinorrhea or weeping, or in any combination (Sur and Plesa, 2015; Kaliner, 2017). AR has been deemed a global health issue and has mostly impacted. Patients suffering from AR may also be concerned regarding mood disorders, sleep disorders, deteriorating social relationships, and may daily activities (Petalas and Durham, 2013; Beard, 2014; Kaliner, 2017). At the same period, AR causes significant morbidity and affects the quality of life. Epidemiological studies indicate that the prevalence of AR, as well as other tropical diseases, has risen worldwide and that AR has infected $10-40 \%$ of the world's total population (Van Cauwenberge et al., 2005; Broek et al., 2010; Kaliner, 2017). AR is a chronic inflammatory reaction in the respiratory tract and is also thought to be a widespread nasal mucosal disease caused by the software of pervasive envy. AR mouse system has been used to study the underlying mechanism contributing

\footnotetext{
Corresponding author: luckydog0730@sina.com 0030-9923/2021/0002-0619 \$ 9.00/0

Copyright 2021 Zoological Society of Pakistan
}

to the development of allergic inflammatory reactions and the effectiveness of anti-allergic drugs (Quillen and Feller, 2006; Kemp, 2009; Dykewicz and Hamilos, 2010; Sur and Plesa, 2015; Kaliner, 2017). Modern pharmacotherapy is used to manage AR such as leukotrine, antihistamines, anticholinergics, leukotriene receptor blocker. On the other side, common $\mathrm{H} 1$ antagonist viz., rupatadine has shown protective effects but interacts with different drug metabolites (Van Cauwenberge et al., 2005; Holgate, 2009; Locksley, 2010; Palm et al., 2012; Kaliner, 2017). The use of anticholinergics and glucocorticoids remains unclear due to long-term adverse effects. Because of its constant operation, a mast cell stabilizer also has serious side effects.

The authors are looking for complementary or alternative medicine/care, such as plant-based medication, to minimize allergic irritation for the management of AR due to side effects of these therapies. However, the exact effects and mechanisms of these strategies are still uncertain in minimizing allergic asthma (Bousquet et al., 2008; Galli and Tsai, 2012; Kaliner, 2017; Kostner et al., 2017). Quercetin, plant flavonol, is the commonly available bioactive element of various fruits, seeds, herbs, grains, kele and red onions. Such foods contain high quercetin content (Park, 2004; D'Andrea, 2015; Li et al., 2016). It has a bitter taste and is used in numerous beverages, dietary supplements and foods as important ingredients. 
Throughout China, Quercetin was used to treat different conditions such as cancer, atherosclerosis, liver disease, and diabetes.

In the traditional Chinese medicine model, quercetin is used to manage inflammation and allergic reaction on the basis of its free radical scavenging study (Formica and Regelson, 1995; Park, 2004; D’Andrea, 2015; Li et al., 2016; Lesjak et al., 2018). In the current experimental study, they investigated quercetin's ability to suppress ovalbumin-induced allergic nasal symptoms and inflammatory cytokine production throughout allergic conditions.

\section{MATERIALS AND METHODS}

\section{Chemicals}

OVA and quercetin were purchased from the Sigma Aldrich (St. Louis, MO), montelukast sodium and cetirizine- $\mathrm{HCl}$ was purchased from the Sigma Aldrich (St. Louis, MO), histamine and serotonin was purchased from the Loba Chemie, Pune, India. All the reagent used in the current experimental study were procured from the reputed vendor.

\section{Experimental animals}

The present experimental study utilized BALB/c mice. The mice were taken from the animal laboratory of the Institute and housed in a polyethylene cage in the departmental animal house. All the mice in the pathogenfree cages are put. The mice are preserved in normal laboratory environment $\left(22 \pm 3^{\circ} \mathrm{C}\right.$; relative humidity of $75 \pm 5$; dark and light period of $12 / 12$ ). The normal regulated diet and water ad libitum was provided for the mice. The entire clinical procedure was carried out in compliance with the academic review board's generic recommendations.

\section{Experimental protocols}

OVA-induced AR model

OVA $(75 \mu \mathrm{g})$ and $\mathrm{Al}(\mathrm{OH})_{3}(2 \mathrm{mg})$ dissolve at regular intervals (days $0,7,14$ and 21) in a phosphate buffer saline
(PBS) $(0.2 \mathrm{~mL})$ and intraperitoneally administered into the mice. A nasal drip of OVA $(500 \mu \mathrm{g}$ in $20 \mu \mathrm{L}$ of PBS) and ordinary water dripped PBS was provided on the days (22-30) after initial administration. Quercetin (1, 10 and $50 \mathrm{mg} / \mathrm{kg}$ ) was administered nasally on days 22-30 before every $1 \mathrm{~h}$ of OVA treatment. The PBS was also collected by the control group mice (Jung et al., 2009).

\section{Estimation of allergic symptoms}

Previously published approach has been used with minor modification to predict allergic symptoms (Jung et al., 2009). Briefly, after exposure of the last allergen, the number of nose rubbing and sneezing motions was counted for $15 \mathrm{~min}$ and compared with the control group, respectively.

\section{Estimation of histamine}

Using the production orders, ELISA assay kits (R\&D Program, Minneapolis, MN) were used to measure histamine (OVA-specific inflammatory factors in the mouse serum).

\section{Estimation of cytokines}

ELISA assay kits (R\&D System, Minneapolis, MN) was used for the estimation of cytokines such as IL-4, IL-5, TNF- $\alpha$, IL-1 $\beta$, IL-10, IgE and INF- $\gamma$ via using the manufacture instructions.

\section{Real-time quantitative PCR (RT qPCR)}

Trizol reagent (Invitrogen) has been used to extract maximum RNA from laboratory mice's regional lymph nodes. Isolated RNA was handled with RNase-free DNAase I (Thermo Fisher Scientific) and cDNA was synthesized using the High Capacity (Thermo Fisher Scientific) cDNA Reverse Transcription Kit. SYBR ${ }^{\circledR}$ Premix Ex TaqTM II package (TaKaRa, Shanghai, China) was used to test the TNF, INF- $\pi$, IL- $1 \beta$ and IL-10 mRNA rates according to the protocol provided by the manufacturer. Relative mRNA levels are evaluated using the $2^{-\Delta \Delta \mathrm{Ct}}$ methods of these genes. Both primers were shown in Table I.

\section{Table I: List of mRNA expression.}

\begin{tabular}{llll}
\hline \multirow{2}{*}{ S. No } & Gene & \multicolumn{2}{c}{ Primer } \\
\cline { 3 - 4 } & & Reverse & Forward \\
\hline 1 & TNF-a & TGGTTTGTGAGTGTGAGGGT & GTGCCTATGTCTCAGCCTCT \\
2 & IL-4 & CCCCAGCTAGTTGTCATCCT & TGGTGTTCTTCGTTGCTGTG \\
3 & IL-5 & TCCATTGCCCACTCTGTACT & GAATCAAACTGTCCGTGGGG \\
4 & IFN- $\gamma$ & CCTTTTTCGCCTTGCTGTTG & AGAGCCAGATTATCTCTTTCTACCTCAG \\
5 & GAPDH & GCCGTGAGTGGAGTCATACT & AGTGTTTCCTCGTCCCGTAG \\
\hline
\end{tabular}




\section{Physiological parameters}

To scrutinize the influence of the tested drug being studied, rhinitis signs are observed and assessed as follows: the amount of rubbing/unit or sneezing periods was recorded in a randomized blind manner immediately for 40 min following nasal task. Sneezing was categorized via an abrupt expiration just after rubbing and intense creativity was categorized with either one or both mice forelimbs via an internal perinasal scrape. Redness found in the nose was investigated by examining and rating the frequency of redness of the nostrils as normal: 0 , faint: 1 , medium: 2 and dark: 3 .

\section{Biochemical parameters}

Determination of nitric oxide (NO)

Griess reagent method was used for the estimation of NO concentration (Ridnour et al., 2000). The absorbance of the sample was estimated at $548 \mathrm{~nm}$ via using the UV visible spectrophotometer. The concentration of nitrite was determined using the standard curve prepared with serial dilutions of sodium nitrite.

\section{Estimation of histamine concentration}

OPA spectrofluorometric was used for the determination of histamine concentration in the serum. The fluorescence intensity of histamine was estimated at $460 \mathrm{~nm}$ using the spectrofluorometric method with minor modification (Jung et al., 2011).

\section{Spleen weight}

At end of the experimental study, followed by the last intranasal challenge, mice were sacrificed and their spleen was separated, moisture was removed by blotting with the filter paper, and the organ weight was taken using a digital weighing balance. The hepatic and spleen were calculated via using the following formula: Spleen/hepatic index $=$ spleen/liver weight $(\mu \mathrm{g}) /$ body weight $(\mathrm{g}) \times 10$, as previously described with minor modification (Aswar et al., 2015).

\section{Preparation of bronchoalveolar lavage fluid (BALF)}

The left lung of all experimental mice were lavage with normal saline $(0.5 \mathrm{~mL})$ to obtain the BALF and centrifuged at $1000 \mathrm{rpm}$ at $4^{\circ} \mathrm{C}$ for $15 \mathrm{~min}$ and collect the cell culture supernatants for the estimation of inflammatory cytokines. Giemsa solution was used for staining the precipitated cells and to count the total cells, eosinophils, lymphocytes, and neutrophils in BALF as classified and based on morphology and staining profile.

\section{Statistical analysis}

Graphpad prism software was used to analyze the experimental data. The data are presented as mean \pm standard deviation. Statistical significance between the experimental groups was compared using the student's t-test or variance analysis. $\mathrm{P}<0.05$ was regarded as statistically significant.
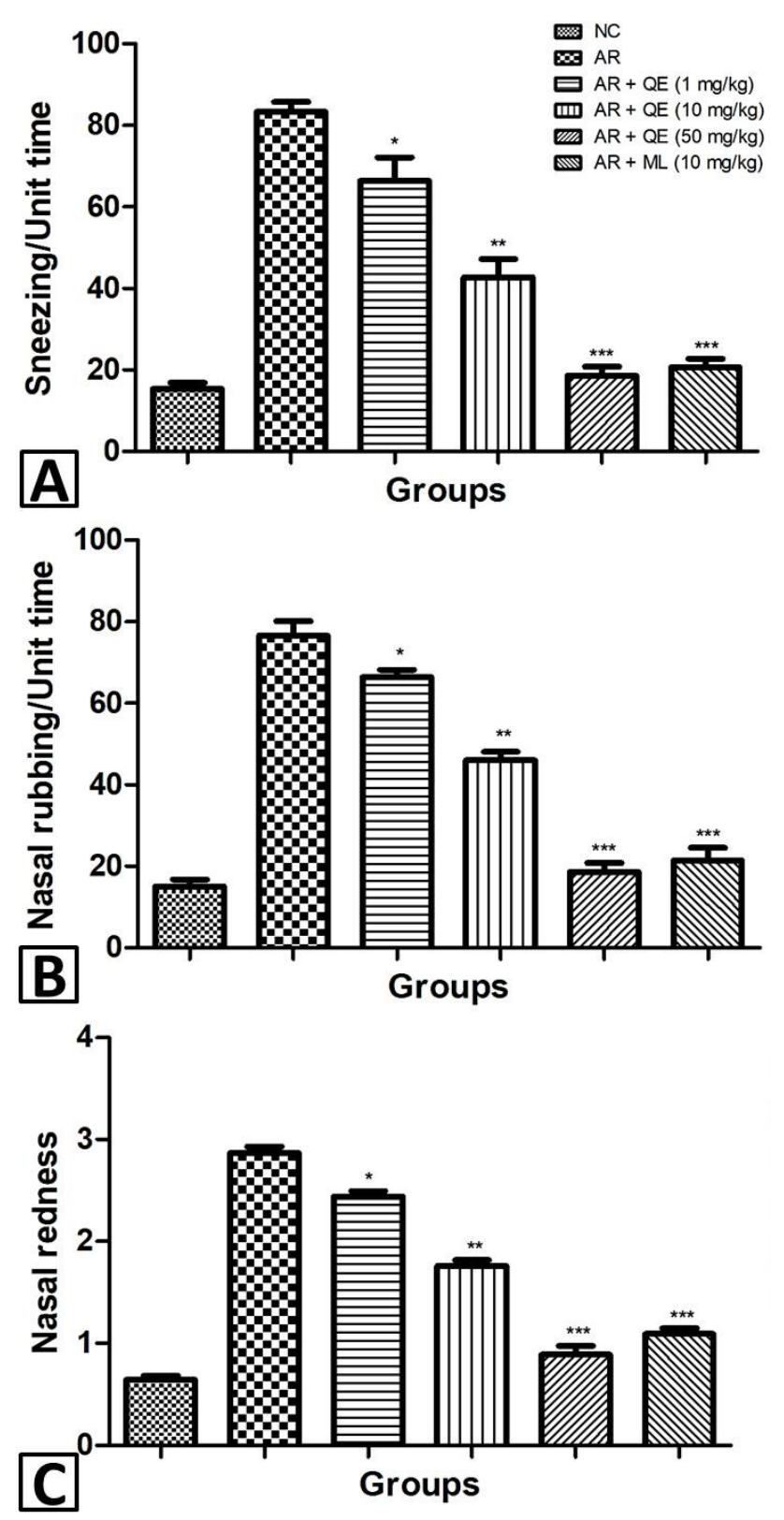

Fig. 1. The effect of qurecetin and montelukast on sneezing, nasal rubbing and nasal redness in OVA induced allergic rhinitis in rats. A, sneezing; B, nasal rubbing; $\mathbf{C}$, nasal redness. The method described in the material and methods. The data are presented in mean $\pm \mathrm{SEM}$. ${ }^{*} \mathrm{P}<0.05,{ }^{*} \mathrm{P}<0.01$ and ${ }^{* * *} \mathrm{P}<0.001$ compared with the $\mathrm{AR}$ control group. 


\section{RESULTS}

\section{Effect of quercetin on allergic parameters}

OVA induced AR mice displayed an increased incidence of allergic in terms of nasal redness, sneezing and nasal rubbing compared to normal group mice. Quercetin $(1 \mathrm{mg} / \mathrm{kg})$ treated mice showed a slight decrease in sneezing, nasal rubbing, and nasal redness frequency. Quercetin $(50 \mathrm{mg} / \mathrm{kg})$ treated community mice reported significant decrease in allergic reactions such as sneezing (Fig. 1A), nasal rubbing (Fig. 2A) and nasal redness (Fig. 1C). Montelukast treated team rats have showed a decrease in allergic reaction relative with mice in the AR control group.

\section{Effect of the quercetin on nitric oxide (NO)}

OVA induced AR mice displayed a higher level of NO, a similar result was found during allergic rhinitis. Dose dependent treatment of quercetin significantly $(\mathrm{P}<0.001)$ decreased the level of NO as compared to OVA induced AR group mice. Montelukast (standard drug) showed the reduced in the level of NO (Fig. 2A).

\section{Effect of quercetin on histamine}

The level of histamine during allergic rhinitis has increased significantly. OVA induced AR group mice displayed elevated histamine levels and quercetin (dose of $100 \mathrm{mg} / \mathrm{kg}$ ) decreased histamine levels near normal control group mice. The histamine rate was also significantly $(\mathrm{P}<0.001)$ reduced by another dosage of quercetin $(1$ and $50 \mathrm{mg} / \mathrm{kg}$ ). Montelukast treated group mice displayed a decreased histamine level compared to the AR control group mice caused by OVA (Fig. 2B).

\section{Effect of quercetin on spleen weight}

The spleen level was significantly increased during allergic rhinitis and strong acceleration was found in the AR control group mice caused by OVA. OVA induced
AR group mice significantly $(\mathrm{P}<0.001)$ increased spleen weight and dose-dependent quercetin therapy significantly reduced spleen weight. A similar result has been observed in the mice treated with Montelukast (Fig. 2C).

\section{Effect of quercetin on pro-inflammatory cytokines}

Figures 3 and 4 showed the effect of pro-inflammatory cytokines on the treated and OVA induced AR group mice. The pro-inflammatory cytokines such as TNF- $\alpha$, IL- $1 \beta$, IL-4, IL-5, IL-6 and IL-10 considerably increased in the OVA induced AR group mice and concentration dependent treatment of quercetin significantly $(\mathrm{P}<0.001)$ reduced the level of pro-inflammatory cytokines.

\section{Effect of quercetin on IFN- $\gamma$ and $\operatorname{IgE}$}

During the allergic reaction, the level of IFN- $\ddot{y}$ and IgE increased significantly. OVA mediated AR group mice displayed increased levels of IFN- $\gamma$ and IgE and significantly $(\mathrm{P}<0.001)$ decreased the rate of dose-dependent quercetin therapy. On the other side, Montelukast $(\mathrm{P}<0.001)$ significantly reduced the IFN- $\gamma$ and IgE levels compared to the AR mice caused by OVA (Fig. 4C, D).

\section{Effect of quercetin on mRNA expression of cytokines}

The effect of quercetin on cytokine mRNA production was shown in Figure 5. OVA-induced AR group mice showed improved expression of TNF- $\alpha$, IL-1 $\beta$, IL-10 and IFN- $\gamma$ and significantly $(\mathrm{P}<0.001)$ reduced the mRNA expression at dose-dependent quercetin therapy.

\section{DISCUSSION}

AR is marked by itchy eyes, sneezing, nasal congestion, lacrimation, and rhinorrhea accompanying signs. AR arises due to multiple mediators signaling which secretes from inflammatory cells and mast cells. It consists of two types of allergic reaction (Thompson et al., 2000; Kilic, 2008). It includes the recruitment of
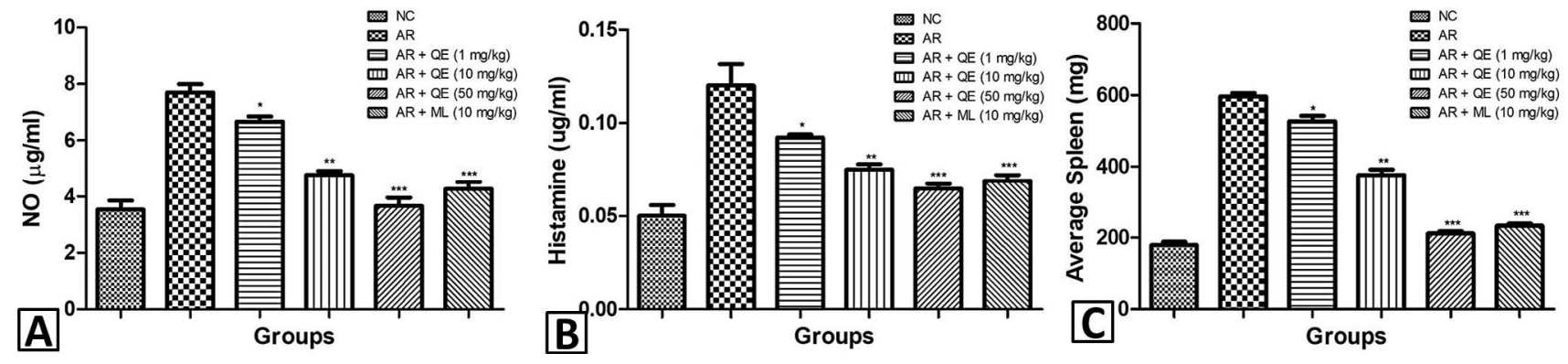

Fig. 2. The effect of quercetin and montelukast on biochemical parameter and spleen weight in OVA induced allergic rhinitis in rats. A, NO; B, histamine; $\mathbf{C}$, spleen weight. The method described in the material and methods. The data are presented in mean \pm SEM. $* \mathrm{P}<0.05,{ }^{*} \mathrm{P}<0.01$ and $* * * \mathrm{P}<0.001$ compared with the AR control group. 

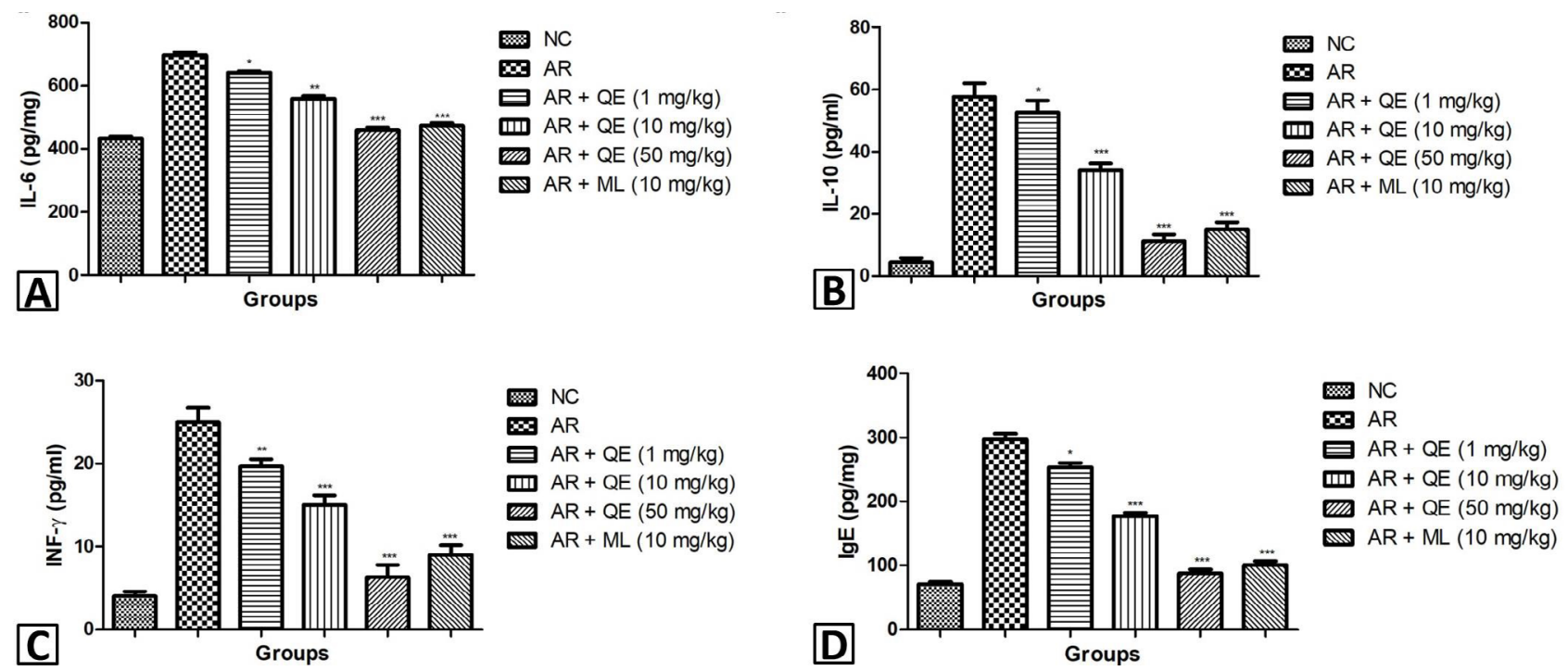

Fig. 3. The effect of quercetin and montelukast on pro-inflammatory cytokines and inflammatory mediators in OVA induced allergic rhinitis in rats. A, IL-6; B, INF- $\gamma$; C, IL-4; D, IgE. The method described in the material and methods. The data are presented in mean \pm SEM. ${ }^{*} \mathrm{P}<0.05,{ }^{*} \mathrm{P}<0.01$ and ${ }^{* * *} \mathrm{P}<0.001$ compared with the AR control group.
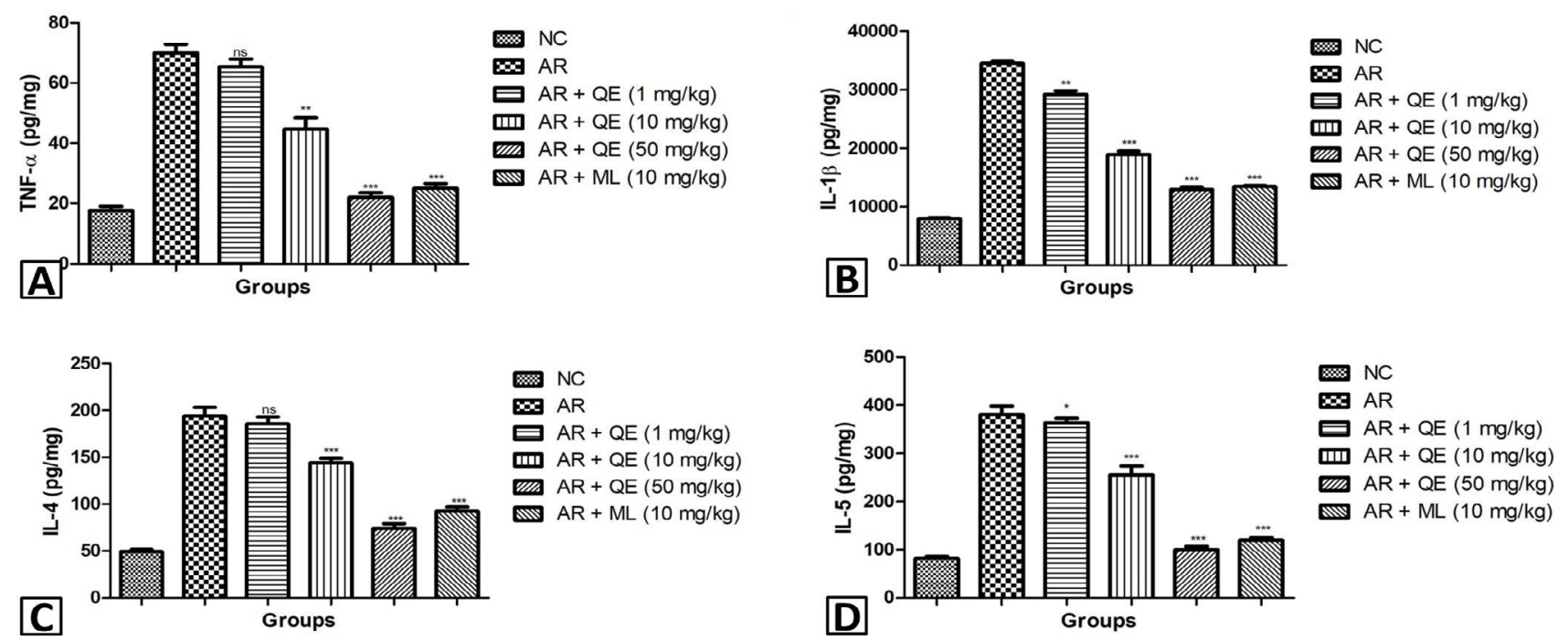

Fig. 4. The effect of quercetin and montelukast on pro-inflammatory cytokines and inflammatory mediators in OVA induced allergic rhinitis in rats. A, IL-6; B, IL-10; C, INF-Y; D, IgE. The method described in the material and methods. The data are presented in mean \pm SEM. ${ }^{*} \mathrm{P}<0.05,{ }^{*} \mathrm{P}<0.01$ and $* * * \mathrm{P}<0.001$ compared with the AR control group.

basophils and mast cells resulting in the production of prostaglandins, leukotrienes, cytokines and histamine in the first step, which causes nasal scratching, sneezing, redness and nasal irritation. The second phase included the movement into the nasal tissue of mast cells, basophils and eosinophils (Girard et al., 1978). The treatment available will either reduce the effect of a mediator's secretion from the cell or the end of the effect of the organ to secrete the mediators. Mast cell stabiliser, H1 receptor antagonist, anti-leukotrienes, anticholinergic agent and corticosteroids are widely used for AR treatment, but all induce severeside effects (Krause, 1995; Baheka et al., 2008). We investigated the anti-allergic activity of quercetin in the OVA-induced allergic system in mice in the present experimental study. In case of allergic rhinitis (AR), the inflammation of the nasal mucosa also extends due to IgE arbitrated reaction (Beard, 2014; Kaliner, 2017). Pro-inflammatory cytokines, neuropeptides, chemokines, cells and numerous sticky 

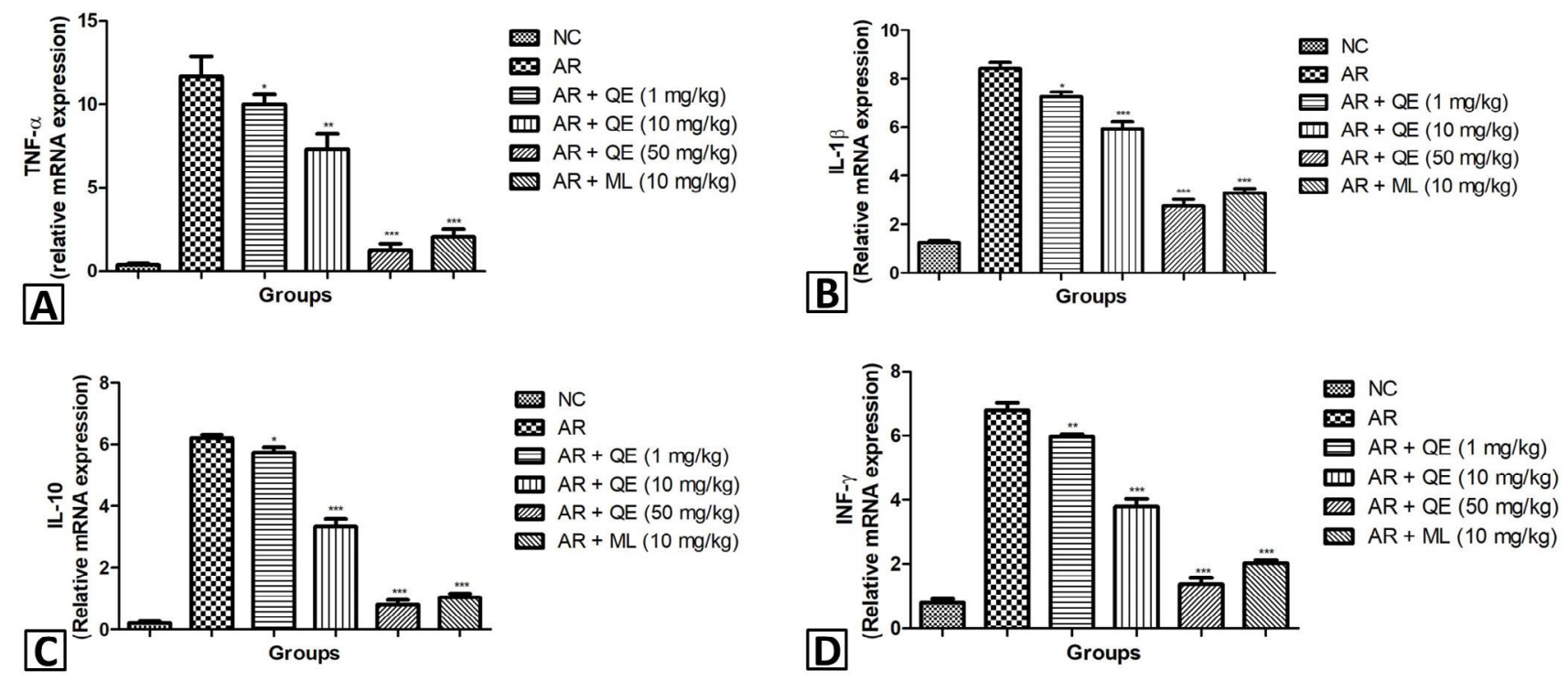

Fig. 5. The effect of quercetin and montelukast on mRNA expression of pro-inflammatory cytokines in OVA induced allergic rhinitis in rats. A, TNF- $\alpha ; \mathbf{B}$, IL-1 $\beta ; \mathbf{C}$, IL- $10 ; \mathbf{D}$, INF- $\Upsilon$. The method described in the material and methods. The data are presented in mean \pm SEM. $* \mathrm{P}<0.05,{ }^{*} \mathrm{P}<0.01$ and $* * * \mathrm{P}<0.001$ compared with the AR control group.

molecules that are active in the inflammatory reaction which interrelate with each other in a complex mixture and also consider as the specific and non-specific symptoms of nasal hyper-reactivity (Amin, 2012; McDonald et al., 2013). We have discussed the nasal signs in the existing research model. The OVA-induced AR model is commonly used to examine the AR effect of the drugs being tested. AR model in the rodent produces nasal allergic symptoms as similar to the human AR (Zhang et al., 2012; McDonald et al., 2013). The objective of the current experimental study was to use the OVA-induced AR model to estimate the antiallergic effect of quercetin. Administration of OVA-induced rhinitis in mice as established on the challenge through the episodes of nasal irritation. The scratching, redness and sneezing caused by sensitization of nerve endings resulting in histamine release in response to antigen-antibody reaction was significantly down-regulated by Quercetin. Previous research suggests that the histamine plays a significant role in the early phase of an allergic reaction in the AR and a significant mediator. The histamine level increased in the sensitized mice during the AR compared to the normal control mice. A similar result was observed in this experimental study, AR control group mice showed the increased histamine level, and dose-dependent quercetin treatment significantly $(\mathrm{P}<0.001)$ decreased histamine level and suggested the antiallergic effect.

In short, nasal itching and nasal discharge commonly used for allergic rhinitis estimation (Kay, 2001). In the current experimental study, the AR control group showed higher scores of nasal itching and nasal discharge compared to the normal control group. Due to up-regulation of hyper-reactivity, AR group mice showed increased nasal symptoms. At the same period, the plasma $\operatorname{IgE}$ rate has already been shown to be higher after the AR. AR control group mice received quercetin significant $(\mathrm{P}<0.001)$ reduced the nasal itching and nasal discharge at dosedependently.

Previous research shows that the AR response starts when the nasal mucosa reacts with the allergen and invasion of inflammatory cells (Sur and Plesa, 2015; Kaliner, 2017). As a result of complex interactions between basophiles, mast cells, B cells and T cells, IgE production begins during the AR. In this phase, pro-inflammatory cytokines such as tumor necrosis factor- $\alpha$ (TNF- $\alpha)$, interleukin- $1 \beta$ (IL-1 $\beta$ ), interleukin-4 (IL-4) and interleukin-5 (IL-5), as well as surface and adhesion molecules, establish contact between $\mathrm{B}$ cells and $\mathrm{T}$ cells, contribute significantly to inflammatory reactions as well. As a result of complex interactions between basophiles, mast cells, B cells and $\mathrm{T}$ cells, IgE production begins during the AR (Petalas and Durham, 2013; Beard, 2014; Sur and Plesa, 2015). As allergens strike the nasal mucosa, this inflammatory response occurs and proceeds through inflammatory cell invasion. The association of basophils, mast cells, T cells and B cells starts IgE expansion (Dykewicz and Hamilos, 2010; Petalas and Durham, 2013; Beard, 2014; Sur and Plesa, 2015). Studies of Despot and Lemanske (1987), Polikepahad et al. (2010) and Amin (2012) suggests that T-helper cell cytokines stimulate the development of allergen-specific IgE by inducing the IgE isotype change 
in interleukin-4 and interleukin-5 cells which contribute to cells such as mast cells, basophils and eosinophils being aggregated and matured (Polikepahad et al., 2010; Uzzaman and Story, 2012). IgE-related allergens induce histamine secretion; prostaglandin D2; leukotrienes (C4, D4 and E4); cytokines and basophils, as well as early and late inflammation (Jeffery and Haahtela, 2006; Kim et al., 2006). Nevertheless, AR's precise pathophysiology is not straightforward and the researcher relies on their work to explore the new strategies of clarifying AR's pathophysiology.

\section{CONCLUSION}

The finding above indicates that quercetin prevented the allergic reaction by mast cell stabilization, thereby that the release of mediators viz., histamine, TNF- $\alpha$, IL- $1 \beta$, IL4, IgE and IL-5. The quercetin's anti-inflammatory activity offered more benefits. The present experimental study indicates the beneficial effect of quercetin on the model of AR caused by OVA; it also predicted that quercetin could be regarded as a possible medicinal medication.

\section{Statement of conflict of interest}

The authors declare no conflict of interest.

\section{REFERENCES}

Amin, K., 2012. The role of mast cells in allergic inflammation. Respir. Med., 106: 9-14. https://doi. org/10.1016/j.rmed.2011.09.007

Aswar, U., Shintre, S., Chepurwar, S. and Aswar, M., 2015. Antiallergic effect of piperine on ovalbumininduced allergic rhinitis in mice. Pharm. Biol., 53: 1358-1366. https://doi.org/10.3109/13880209.201 4.982299

Baheka, P.C., Shah, J.H., Ayer, U.B., Mandhane, S. and Thennate, R., 2008. Validation of guinea pig model of allergic rhinitis by oral and topical drugs. Int. Immunopharmacol., 8: 1540-1551. https://doi. org/10.1016/j.intimp.2008.06.010

Beard, S., 2014. Rhinitis. Prim. Care Clin. Off. Pract., 2: $233-236$.

Bousquet, J., Khaltaev, N., Cruz, A.A., Denburg, J., Fokkens, W.J., Togias, A., Zuberbier, T., BaenaCagnani, C.E., Canonica, G.W., Van Weel, C., Agache, I., Aït-Khaled, N., Bachert, C., Blaiss, M.S., Bonini, S., Boulet, L.P., Bousquet, P.J., Camargos, P., Carlsen, K.H., Chen, Y., Custovic, A., Dahl, R., Demoly, P., Douagui, H., Durham, S.R., Gerth Van Wijk, R., Kalayci, O., Kaliner, M.A., Kim, Y.Y., Kowalski, M.L., Kuna, P., Le, L.T.T., Lemiere, C., Li, J., Lockey, R.F., Mavale-Manuel,
S., Meltzer, E.O., Mohammad, Y., Mullol, J., Naclerio, R., O’Hehir, R.E., Ohta, K., Ouedraogo, S., Palkonen, S., Papadopoulos, N., Passalacqua, G., Pawankar, R., Popov, T.A., Rabe, K.F., RosadoPinto, J., Scadding, G.K., Simons, F.E.R., Toskala, E., Valovirta, E., Van Cauwenberge, P., Wang, D.Y., Wickman, M., Yawn, B.P., Yorgancioglu, A., Yusuf, O.M., Zar, H., Annesi-Maesano, I., Bateman, E.D., Ben Kheder, A., Boakye, D.A., Bouchard, J., Burney, P., Busse, W.W., Chan-Yeung, M., Chavannes, N.H., Chuchalin, A., Dolen, W.K., Emuzyte, R., Grouse, L., Humbert, M., Jackson, C., Johnston, S.L., Keith, P.K., Kemp, J.P., Klossek, J.M., Larenas-Linnemann, D., Lipworth, B., Malo, J.L., Marshall, G.D., Naspitz, C., Nekam, K., Niggemann, B., Nizankowska-Mogilnicka, E., Okamoto, Y., Orru, M.P., Potter, P., Price, D., Stoloff, S.W., Vandenplas, O., Viegi, G. and Williams, D., 2008. Allergic Rhinitis and its Impact on Asthma (ARIA) 2008 update (in collaboration with the World Health Organization, GA2LEN and AllerGen). Allergy, 63(Suppl-86): 8-160. https:// doi.org/10.1111/j.1398-9995.2007.01620.x

Broek, J.L., Bousquet, J., Baena-Cagnani, C.E., Bonini, S., Canonica, W., Casale, T.B., van Wijk, R.G., Ohta, K., Zuberbier, T. and Schünemann, H.J., 2010. Allergic rhinitis and its impact on asthma (ARIA) guidelines: 2010 revision. J. Allergy clin. Immunol., 126: 466-476. https://doi.org/10.1016/j. jaci.2010.06.047

D’Andrea, G., 2015. Quercetin: A flavonol with multifaceted therapeutic applications? Fitoterapia, 106: 256-271.

Despot, J.E. and Lemanske, R.F., 1987. Inflammatory mediators in allergic rhinitis. Immunol. Allergy Clin. N. Am., 114(Suppl-5): S135-138. https://doi. org/10.1016/j.jaci.2004.08.043

Dykewicz, M.S. and Hamilos, D.L., 2010. Rhinitis and sinusitis. J. Allergy clin. Immunol., 125(Suppl-2): S103-115. https://doi.org/10.1016/j. jaci.2009.12.989

Formica, J.V, Regelson, W., 1995. Review of the biology of quercetin and related bioflavonoids. $F d$. Chem. Toxicol., 33: 1061-1080.

Galli, S.J. and Tsai, M. 2012. IgE and mast cells in allergic disease. Nat. Med., 18: 693-704. https:// doi.org/10.1038/nm.2755

Holgate, S.T., 2009. Pathogenesis of asthma. In: Allergy and allergic diseases, $2^{\text {nd }}$ ed. 38: 872-897. https:// doi.org/10.1111/j.1365-2222.2008.02971.x

Girard, J.P., Cuevas, M. and Heimlich, E.M., 1978. A placebo controlled double-blind trial of beclomethasone dipropionate in the treatment of 
allergic rhinitis. Allergol. Immunopathol. (Madr.), 6: 109-116.

Jeffery, P.K. and Haahtela, T., 2006. Allergic rhinitis and asthma: Inflammation in a one-airway condition. BMC Pulm. Med., 6(Suppl-1): S5. https://doi. org/10.1186/1471-2466-6-S1-S5

Jung, H.W., Jung, J.K. and Park, Y.K., 2011. Antiallergic effect of Ostericum koreanum root extract on ovalbumin-induced allergic rhinitis mouse model and mast cells. Asian Pacific J. Allergy Immunol., 29: $338-348$.

Jung, W.K., Choi, I., Oh, S., Park, S.G., Seo, S.K., Lee, S.W., Lee, D.S., Heo, S.J., Jeon, Y.J., Je, J.Y., Ahn, C.B., Kim, J.S., Oh, K.S., Kim, Y.M., Moon, C. and Choi, I.W., 2009. Anti-asthmatic effect of marine red alga (Laurencia undulata) polyphenolic extracts in a murine model of asthma. Fd. Chem. Toxicol., 47: 293-297. https://doi.org/10.1016/j. fct.2008.11.012

Kaliner, M.A., 2017. Allergic rhinitis. Neuropeptides Respirat. Med., 90: 699-704. https://doi. org/10.4324/9780203745915-26

Kay, A.B., 2001. Allergy and allergic diseases. $N$. Engl. J. Med., 344: 30-37. https://doi.org/10.1056/ NEJM200101043440106

Kemp, A.S., 2009. Allergic rhinitis. Paediatr. Respir. Rev., 10: 63-68. https://doi.org/10.1016/j. prrv.2009.02.002

Kilic, G., 2008. Treatment of allergic rhinitis in children. Antiinflamm. Antiallergy Agents Med. Chem., 7: 3844. https://doi.org/10.2174/187152308783769186

Kim, S.H., Jun, C.D., Suk, K., Choi, B.J., Lim, H., Park, S., Lee, S.H., Shin, S.Y., Kim, D.K. and Shin, T.Y., 2006. Gallic acid inhibits histamine release and pro-inflammatory cytokine production in mast cells. Toxicol. Sci., 91: 123-131.

Kostner, L., Anzengruber, F., Guillod, C., Recher, M., Schmid-Grendelmeier, P. and Navarini, A.A., 2017. Allergic contact dermatitis. Immunol. Allergy Clin. N. Am., 37: 141-152. https://doi.org/10.1016/j. iac.2016.08.014

Krause, H.F., 1995. Pharmacotherapy of perennial and seasonal allergic rhinitis. Clin. Immunother., 3: 308. https://doi.org/10.1007/BF03259282

Lesjak, M., Beara, I., Simin, N., Pintać, D., Majkić, T., Bekvalac, K., Orčić, D. and Mimica-Dukić, N., 2018. Antioxidant and anti-inflammatory activities of quercetin and its derivatives. J. Funct. Foods, 40: 68-75. https://doi.org/10.1016/j.jff.2017.10.047

Li, Y., Yao, J., Han, C., Yang, J., Chaudhry, M.T., Wang, S., Liu, H. and Yin, Y., 2016. Quercetin, inflammation and immunity. Nutrients, 8: 167. https://doi.org/10.3390/nu8030167
Locksley, R.M., 2010. Asthma and allergic inflammation. Cell, 140: 777-783. https://doi.org/10.1016/j. cell.2010.03.004

McDonald, J.L., Cripps, A.W., Smith, P.K., Smith, C.A., Xue, C.C. and Golianu, B., 2013. The antiinflammatory effects of acupuncture and their relevance to allergic rhinitis: A narrative review and proposed model. Evidence-Based Complement. Altern. Med., 2013: Article ID 591796. https://doi. org/10.1155/2013/591796

Palm, N.W., Rosenstein, R.K. and Medzhitov, R., 2012. Allergic host defences. Nature, 484: 465-472.

Park, J.B., 2004. Quercetin. Encyclopedia Diet. Suppl., 21: 623. https://doi.org/10.1201/b13959-60

Petalas, K. and Durham, S.R., 2013. Allergen immunotherapy for allergic rhinitis. Rhinology, 51: 99-110. https://doi.org/10.4193/Rhin12.86

Polikepahad, S., Knight, J.M., Naghavi, A.O., Oplt, T., Creighton, C.J., Shaw, C., Benham, A.L., Kim, J., Soibam, B., Harris, R.A., Coarfa, C., Zariff, A., Milosavljevic, A., Batts, L.M., Kheradmand, F., Gunaratne, P.H. and Corry, D.B., 2010. Proinflammatory role for let-7 microRNAS in experimental asthma. J. biol. Chem., 285: 3013930149. https://doi.org/10.1074/jbc.M110.145698

Quillen, D.M. and Feller, D.B., 2006. Diagnosing rhinitis: Allergic vs. nonallergic. Am. Fam. Physician, 73: 1583-1590.

Ridnour, L.A., Sim, J.E., Hayward, M.A., Wink, D.A., Martin, S.M., Buettner, G.R. and Spitza, D.R., 2000. A spectrophotometric method for the direct detection and quantitation of nitric oxide, nitrite, and nitrate in cell culture media. Anal. Biochem., 281: 223-229. https://doi.org/10.1006/abio.2000.4583

Sur, D.K.C. and Plesa, M.L., 2015. Treatment of allergic rhinitis. Am. Fam. Physician, 92: 985-992.

Thompson, A.K., Juniper, E. and Meltzer, E.O., 2000. Quality of life in patients with allergic rhinitis. Annls. Allergy Asthma Immunol., 85: 338-348.

Uzzaman, A. and Story, R., 2012. Allergic rhinitis. Allergy Asthma Proc., 1: 15-18. https://doi. org/10.2500/aap.2012.33.3535

Van Cauwenberge, P., Van Hcecke, H. and Bousquet, J., 2005. Allergic rhinitis and its impact on asthma. In: Pediatric nasal and sinus disorders. J. Allergy clin. Immunol., 108(Suppl-5): S147-334.

Zhang, N., Van Crombruggen, K., Holtappels, G. and Bachert, C., 2012. A herbal composition of Scutellaria baicalensis and Eleutherococcus senticosus shows potent anti-inflammatory effects in and ex vivo human mucosal tissue model. Evidencebased Complement Altern. Med., 2012: Article ID 673145. https://doi.org/10.1155/2012/673145 